\title{
Prevalence of resistance-associated substitutions to direct-acting antiviral agents in hemodialysis and renal transplant patients infected with hepatitis C virus [Erratum]
}

\author{
Tavares RCF, Feldner AC, Pinho JR, et al. Infect Drug Resist. \\ 2018;11:1993-2000.
}

Page 1999, reference 40 was listed incorrectly. "Alves da Silva R. Molecular characterization of hepatitis $\mathrm{C}$ virus in end-stage renal disease patients under hemodialysis. Journal of Medical Virology 90. 2018;3:537-544." should read “Alves da Silva R, Todão JS, Kamitani FL, et al. Molecular characterization of hepatitis $\mathrm{C}$ virus in end-stage renal disease patients under hemodialysis. Journal of Medical Virology 90.

2018;3:537-544." access journal that focuses on the optimal treatment of infection (bacterial, fungal and viral) and the development and institution of preventive strategies to minimize the development and spread of resistance. The journal is specifically concerned with the epidemiology of antibiotic

resistance and the mechanisms of resistance development and diffusion in both hospitals and the community. The manuscript management system is completely online and includes a very quick and fair peerreview system, which is all easy to use. Visit http://www.dovepress.com/ testimonials.php to read real quotes from published authors. 